\title{
Analysis of Psycological Disorder Tedency for Polygamous Women Reproductive Health in Pamekasan Madura
}

\author{
Emi Yunita ${ }^{1}$ \\ Byba Melda ${ }^{2}$, Koesnadi ${ }^{2}$ \\ ${ }^{1}$ Magister of Health Study \\ Program of Institut Ilmu \\ Kesehatan STRADA Indonesia \\ ${ }^{2}$ Lecturer of Institut Ilmu \\ Kesehatan STRADA Indonesia \\ Email: \\ nitayunitaa11@gmail.com
}

Received : October 12, 2019

Accepted : February 13, 2020

Published : May 10, 2020

\begin{abstract}
The majority of polygamous marriages in Indonesia are only based on law and religion, regardless of the effects of polygamy. The lack attention public about the psychology that occurs in polygamous women. While, the impact of psychological disorders itself can affect to female hormones that can be caused to a reproduction system. The reproductive system can also experience disorders due to illness or abnormalities. The diseases of the reproductive system can be caused by germs, genetic factors, or hormones. Women have complex problems around their reproductive lives. Disorders of the female reproductive system can include menstrual disorders, vaginal cancer, cancer cervix, ovarian cancer, genetalia cancer, endometriosis, vaginal infections, vaginal discharge or fluorine, and Ghonorrhea. The purpose of this study is to explore the occurrence of psychological disorders that affect the reproductive health of polygamous women. The research design used is qualitative research with a phenomenological approach. The data collection in this study used in-depth interview techniques with semi-structured questions with a sample of 10 informants. From the results of the study indicate that the analysis of psychological disorders that have an impact on women's reproductive health in polygamy has good benefits for health workers and for the community, especially women. In analyzing the tendency of psychological disorders that affect the reproductive health of women who are polygamous there are many things that can be used as references on how the effects of polygamous marriages are related to women's reproductive health, both negative and positive impacts. In analyzing the trends of production in polygamous women there are some hopes of supporting improvements in public health, especially women's reproductive health. Based on this research, further research is needed on the analysis of trends in the occurrence of psychological disorders that have an impact on reproductive health in polygamous women in Pamekasan Madura.
\end{abstract}

Keywords: Polygamous, psychological problems, reproductive problem

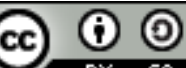

This is an open-acces article distributed under the terms of the Creative Commons Attribution-ShareAlike 4.0 International License. 


\section{INTRODUCTION}

Marriage according to Papalia \& Old is a bond formed between men and women in it including intimacy, friendship, fulfillment of sexy desires and becoming more mature (in Gladiani, 2013). Marriage itself is the most important form of relationship in the lives of most adults (Pincus in Nina, 2009). Marriage is commonly found throughout the world, namely Unregistered Marriage, namely marriage between one husband and one wife. This is the same as that issued by Duvall and Miller. They appreciate that the marriage is monogamous. Monogamus itself is a pairing relationship between one woman and one man (Duvall and Miller in Gladiani, 2013).

However, nowadays, the model of marriage that occurs in society is not just Unregistered Marriage. There are other marriage models, namely polygamy, polyandry and marriage groups (Murdock in Nina, 2009). Until now, marriage allowed in Indonesia itself is only a form of monogamy and polygamy. the polygamy marriage model itself is a marriage model where a husband has more than one wife at a time (Zeitzen, 2008).

In Indonesia itself, polygamous marriages that occur every year are increasing. As data obtained from antaranews.com that in 2004 there were 1016 who filed polygamy permits, then in 2006 there were 1148 who filed polygamy permits at the Religious Courts. In addition, there are also seminars held throughout Indonesia that socialize polygamous marriage. Like a seminar with the theme "Polygamy Effective Medicine to Get Love of God" organized by the Global Brotherhood community on October 17, 2009 and took place at the Grand Aquilla Hotel Bandung. The event was attended by 170 invitations from various regions in Indonesia. Then the seminar organized by DaurohPoligamiIndonesia.com in Surabaya on April 8, 2018 with the theme "Masterclass - Quick Ways to Get 4 Wives". And the latest is a seminar held in Jakarta on July 29, 2018 with the theme "National Polygamy Class".

The trend shows that in Indonesia itself, polygamous marriage has become a familiar thing. the trend also shows that the majority of polygamous marriages in Indonesia are only based on law and religion. Whereas if viewed from another perspective, polygamy can have psychological impacts and health impacts, both negative and positive impacts. The psychological impacts are also not only for his wives who must be willing to share their husbands, husbands also have psychological effects, both positive and negative. This happens because the husbands who do polygamy must take care, be responsible and pay attention to two or more households.

Where the psychological impact itself can affect the health impact, namely in the form of changes in female hormones that can result in disruption in the reproductive system of women. Reproductive systems can also experience disorders due to disease or abnormalities. Diseases of the reproductive system can be caused by germs, genetic factors, or hormones. Women have a variety of complex problems surrounding their reproductive life. Disorders of the female reproductive system can include menstrual disorders, vaginal cancer, cervical cancer, ovarian cancer, genetalia cancer, endometriosis, vaginal infections, vaginal discharge or fluorine, and gonorrhea.

The lack of public attention regarding the psychological impact and health impacts that occur on the perpetrators of polygamy, makes the researchers become interested in studying this matter. Thus, this study is entitled "Analysis of Trends in the Occurrence of Psychological Disorders that affect the reproductive health of women who are polygamous in Pamekasan Regency".

\section{METHODS}

This study uses a qualitative research design with a phenomenological approach. In this study data collection used in-depth interview techniques with semi-structured questions. The sampling technique in this study used purposive sampling with a sample of 10 informants from 12 informants. The criteria for the validity of the data in this study refer to the four criteria mentioned by Moleong (2007), namely the degree of credibility, transferability, dependability and confirmability. And this research has passed the ethical test conducted at Institut Ilmu Kesehatan STRADA Indonesia.

\section{RESULTS}

Reasons for the marriage of polygamy by a husband In women who experience psychological disorders that have an impact on reproductive health in Pamekasan

The theme of the reason for the occurrence of polygamy is built on what factors are behind the occurrence of polygamous marriages carried out by the husband both on the first or second wife and so 
on. Interviews with 10 informants about the reasons for polygamy marriage were obtained from interviews and the answers were generated from both parties to polygamous marriages, both from their wives and from their husbands.

Duration The conduct of polygamous marriages in women who experience psychological disorders and has an impact on reproductive disorders in Pamekasan

The Old Theme or the time period for which a polygamous marriage is carried out by informants is diverse. The results of interviews with 10 informants about the length of time or the period of time the informants undergo polygamous marriages ranging from 2 years to 10 years

Positive Impact of Polygamy Marriage from Women who experience psychological disorders that have an impact on Women's Reproductive Health in Pamekasan.

Positive impact themes from polygamous marriages in polygamous women who experience psychological disorders that affect women's reproductive health there are some who feel. The results of interviews with 7 informants about the positive impact of polygamous marriages that they lived in were "nonexistent" and from the two respondents said there were good things to get from polygamous marriages or the positive effects of polygamous marriages that I lived

Negative impacts of polygamous marriages on women who experience psychological disorders that have an impact on women's reproductive health in Pamekasan.

The theme of the negative impact of polygamous marriages undertaken by women with psychological disorders that have an impact on the reproductive health of women in Pamekasan, all have a negative impact. The results of interviews with 10 informants about the negative impact of polygamy marriage that they lived were stress, reduced welfare, affection of the husband reduced, interference reproduction and felt no husband

Approval of Wives on husbands to remarry women who are polygamous and experience psychological disorders that affect women's reproductive health.

Theme: Wife's consent to a husband by a woman who has a psychological disorder that has an impact on the health of women who are polygamous in Pamekasan. The results of interviews with 10 informants about the wife's agreement were obtained - the average wife did not approve of her husband marrying again, but there were some of them who gave consent because of things

Handling the impact on polygamy marriages by women with psychological disorders that affect reproductive health in polygamous women in Pamekasan.

The theme of handling negative impacts experienced by women who are polygamy with psychological disorders that have an impact on their reproductive health, namely by visiting several health workers to find out their condition and get medical treatment and pray for patience. The results of interviews with 10 informants about the handling of the negative effects on women who were polygamous with psiology disorders and had an impact on their reproductive health.

The status of polygamy carried out by women who experience psychological disorders that have an impact on the reproductive health of women who are polygamous in Pamekasan.

The theme of the status of polygamy by women who experience psychological disorders that have an impact on the reproductive health of women in polygamy in Pamekasan, namely the average status of polygamy with marriages under the hand, or just religiously valid. Interviews with 10 informants about the status of polygamous marriages were obtained with 10 polygamous status with religiously valid marriages or underhanded marriages, while the other 2 were officially polygamous, which were submitted through the local religious court.

The reproductive health patterns of life of women who experience psychological disorders that have an impact on the reproductive health of women who are polygamous in Pamekasan

The theme of the reproductive health pattern of women who experience psychological disorders that affect reproductive health of women who are polygamous in Pamekasan, namely 8 informants use contraception and there is no prohibition from their husbands to use family planning, the informant also 
said that the polygamous marriage status changes., unlike before polygamy, and 2 informants never used contraception because they hoped to have offspring immediately, but it turned out that the informant had infertility.

\section{DISCUSSION}

From the results of research on the reasons for polygamy. From the results of this study, several reasons for polygamy were varied, including due to heredity, responsibility, business or for a good institution, economic background, marriage background with his previous wife, or by reason of the absence of cheating between husband and wife and husband's factor who feels his wife is unable to provide service or do it perfectly and on the basis of responsibility because of a problem that concerns the life and future of a woman with a widow status. As expressed by informants 5 and 10, the polygamous marriage they live is because they are not able to give offspring so that her husband chooses to do polygamy to get offspring or a child.

Polygamy is a form of marriage that is currently undeniable and has been happening a lot in Indonesia and the number is increasing every year. Polygamy marriage itself is not a form of marriage that is easy to do because polygamous marriages create conflicts between women and their wives and children (Nailiya, 2016)

Undergoing the practice of polygamy requires physical, psychological, and spiritual preparedness from husband, wife, and all family members. A wife who cannot accept the fact that her husband has polygamy will generally experience emotional instability. The wife becomes sensitive, irritable, uncontrolled attitude because her emotions are more often involved, easily sad and often suspiciously excessive (Soewondo, 2001, h.160)

For husbands, they must take care, be responsible and pay attention to two or more household units, he must change his attitude and behavior. Demands to share time, finance, personal and others as fairly as possible. The family function must be run for two or more household units. These things are not an easy thing to do, so that in the QS. An-Nisa itself it is affirmed that if it is indeed unable to be fair to his wives and families then there is no need for polygamy intimate (Faridl, 2007).

Polygamy marriages in the Pamekasan Madura region seem to have become commonplace, especially for prominent figures who actually feel proud if they are able to have more than one wife, which is considered by some to be a symbol of prosperity and quality of life is far more both of couples who do not do polygamy, they think all their needs are better able to get and get more psychological and physical satisfaction.

It is no different from a husband - a husband who feels proud of his ability to have more than one life or wife, as well as a woman who is honey from a polygamous marriage, some of them also feel proud to be honey if her husband is respected and respected by the community, such as a village head or cleric, where the regency of Pamekasan is an area with a very high religious life, where there are many Islamic boarding schools as well as descendants of quite famous kyai.

Whereas for wives, especially first wives, inferior feelings will arise in him because he thinks that polygamy occurs because he is considered unable to fulfill his desires or serve his husband. Not infrequently the first wives thought that he was someone who was worthless especially in the eyes of her husband

Judging from the length of polygamous marriage, the results of the study showed that polygamous marriages of 10 informants varied, ranging from those who had lived for two years to ten years, but a longer amount of time did not mean becoming a more perfect polygamous marriage, such as one informant, had been married to polygamy for 10 years, but there was never an agreement or had a minimum recognition that her husband had the same responsibility towards him to other women, even for 10 years the informant felt very much at a loss of time, felt he was accepted and the husband preferred linger with another woman.

Marriage is very important in the lives of people, individuals and groups with legitimate marriages, male and female associations become respected as human beings are respected creatures. The association of married life is fostered in an atmosphere of peace, serenity, and compassion between husband and wife. Childhood from legal marriage adorns family life and at the same time is a clean and respectful human survival (Putri, 2010)

The importance of talking about marriage, especially when we review the marriage on the archipelago, of course, from tens to hundreds of ethnic groups in the archipelago, there are various 
types of ways and traditions of marriage, depending on the customs and traditions of each tribe and nation. As with any method and custom of marriage, it is not a problem, it means that during the marriage it still recognizes the principles of survival and mutual respect for the rights of each individual without leaving religiously determined lines (Hasanah, 2012)

In accordance with the above theory that marriage is an important matter and is a necessity for the marriage method, during the marriage it acknowledges the principles of survival and mutual respect for the rights of every individual, as well as the polygamous marriage relationship that informants live, all depends on the individual each, not guided by the length of a relationship, but rather on how to live it, there are polygamous marriages that are still two years old but capable of creating a harmonious situation and being able to respect each other's rights rather than having a unregistered marriage relationship for longer, but the existing relationship still cannot be mutually

Judging from the positive impact of polygamous marriages, the results of the study said that among the 10 informants who felt that there were positive impacts on polygamy marriage they were carried out by 3 informants, informants 2, 5 and 10. Where the informant 2 said the polygamous marriage was one of the ways certainly able to produce an advancement in a pesantren because the marriage bond is considered to strengthen relations with other extended families, and two other informants namely informants 5 and 10 have the same reasons, namely hereditary factors.

From several studies it has been found that the practice of polygamy does indeed produce various effects, both positive and negative. One of them is as mentioned by Shalala (in Ariyani, 2004) that polygamy will be more profitable for men than women. One of them is to be able to increase prestige before the public because they have many wives.

The aim of polygamy in Islam is to perfect the aid and benefits that are in accordance with the polygamy of the Prophet who have humanitarian goals, the community and his purpose in marriage. The use of polygamy for social life is that more and more population increases and the number of births increases and the number of women not married, so that the polygamy solution is suitable for implementation

The policy of polygamy is in accordance with the phenomena and needs that continue to change in every place and situation, everything that has been applied in this religion is nothing but the value of wisdom and law as contained in polygamy (karim Hilmi, 2007)

Everything in all problems must have a negative impact or positive impact, as well as polygamy marriage which in this study there are some who feel the positive impact, and with that the quality of the family of the polygamous couple can be said to be better than before, because a marriage is wrong but the goal is to get descendants, where a family is considered perfect when they have offspring. in addition to feeling their perfection, they also said that more and more friends were sharing, so here it can be believed that in polygamous marriages according to religious advice, adjusted for reasons and readiness in terms of fairness, how to maintain the rights of each wife.

In addition to the positive impacts outlined above in this study researchers also explored the negative impact of polygamous marriage in this study on the negative impacts experienced by women in polygamy, all women experienced negative effects in the form of health problems, in the form of psychological disorders and reproductive disorders. Psychological disorders experienced by polygamous women in this study are psychological disorders in the form of stress and mild depression. And reproductive disorders experienced by women experienced by polygamous women include menstrual cycle disorders, disminore, vaginal discharge and abortion, and infertility.

Some disadvantages for women are mentioned by Shalala (in Ariyani, 2004). from the analysis that all the informants felt pressured even though some said they were happy. This is the same as the results of research conducted by Ariani that women in polygamy can cause personality pressures, such as jealousy, personality conflicts, competition, and children's displeasure with different mothers. Jones (in Ariyani, 2004) added through the results of his research on women of the Sasak tribe in Lombok that polygamy resulted in things such as nightmares, fate surrender, wives between wives, feelings of betrayal by husbands, suicide, and even going crazy. Some of the effects of polygamy on a wife are as follows: 


\section{Psychological impact}

Feeling inferior to the wife and blaming herself for feeling that the act of polygamy husband is a result of her inability to fulfill her husband's biological needs. This was experienced by informants 1 who felt like killing people, while informant 2 had hit another wife from her husband until she fainted.

\section{Impact of the household economy}

Economic dependence on husband. Although there are some husbands, they can be fair to their wives, but in practice it is more often found that husbands are more concerned with young wives and abandon their wives and children beforehand. As a result, wives who do not have jobs will find it very difficult to cover their daily needs. This hali was also experienced by the informants of the first 4 wives who were struggling with economic rations. Informant 4 is often angry with her husband who gives his wife more financially than his first wife. While Jamruhi (2006) mentions some of the negative influences of polygamy on wives as follows:

The arising of envy and hostility among wives. This feeling usually arises because the husband loves one wife more than the other wife or because of lack of justice. However, this rarely happens when a husband and wife understand their rights and obligations.

The feelings above can also be inherited to the children of each wife so they do not have a sense of brotherhood.

The emergence of inner pressure on the first wife because usually the husband will love his new wife more. This feeling resulted in the first wife feeling less happy in her life.

The negative impact of marriage in this research is very much felt by women who are polygamous from all elements, both psychological, health problems, social, economic problems and others, their tendency to feel demeaned is very high, it can be seen from one of the informants' confessions, since polygamy seldom left the house and chose to be more quiet because they did not want to be gossiped by the surrounding community, where in this case their social life was no longer considered normal, which indeed needed to be reviewed about the decision to polygamy. Because not only that, psychological children and children's lives will feel disturbed by the marriage status of polygamous parents.

A first wife who felt betrayed was even more sensitive and irritable. He becomes easy to grieve and often feels suspicious, he will feel jealousy because he feels her husband loves his new wife more than he does. Not infrequently also the first wives feel lonely or feel alone because they lose contact with the people around them. He is more often alone. Then for the other wives too, jealousy must exist and still appear, even though he knew from the beginning that he was made into his second wife by her husband, but the feeling of wanting to be united would still appear, and not infrequently they felt stressed and stressed because feel constantly gossiped by the surrounding community.

Stress is very influential on both male and female reproductive organs. Women will be susceptible to menstrual disorders and vaginal infections, while men may be affected by impotence and premature ejaculation. Hormone is also not merely the influence of a bad lifestyle, but also a major influence in the long run, this can affect the chances of producing offspring for men and women (infertile).

The agreement given by the wife to the husband to commit polygamy in this study on average polygamous marriages that occur not with prior wife approval or polygamous women, but there are some previous wives or polygamous women who consent to their husbands to remarry with considerations of course they have thought well. Like the informants 2.5 , and 10 who gave their husbands approval to remarry, both began with inner conflict and did not. For example, as informant 5 , he actually asked her husband to remarry to get offspring without thinking, because basically the informant himself also very able to have offspring even not from his own womb.

The polygamy marriage carried out by the man and his wife, both the second and third wives whose marriage process did not pass the first permission request to his wife or the request for permission from the court, also violated the concept and law on polygamy marriage in Indonesia. As noted, Indonesia as a legal state discussed the issue of polygamy with a very detailed discussion. Clearly there are more or less 5 guidelines as a rule about polygamy, namely Law No. 1 of 1974, PP No. 9 of 1975, PP No. 10 of 1983, PP No. 45 of 1990, and Compilation of Islamic Law (KHI). Based on Law No. 1 of 1974 which states that the family system adopted by the State of Indonesia is even though in principle a person must be monogamous / monogyny but in the following explanation allows a person to 
polygamy, provided that the court can give permission to the husband to polygamy with the consent of the parties concerned.

Some research results also say that only a few percent of women who agree to polygamy, such as the results of a survey from the LSI collaboration, Goethe Institute, Friedrich Nauman Stiftung and Fur Die, Freiheit in November 2010 showed that of 1496 respondents, $0.8 \%$ strongly supported polygamy, $12.7 \%$ agree with polygamy, $52.9 \%$ reject polygamy, $32.9 \%$ strongly oppose polygamy and $0.6 \%$ abstain (Goethe Institut, 2010).

From the results of several studies also said that seen from several aspects of polygamy can harm many parties both their own husbands and wives and children who become victims. As the results of research (Dickson, 2007) explain that the factors that influence the view about polygamy are observations of polygamy. The practice of polygamy that occurs a lot is actually detrimental to the family. Research conducted (Ratnaningsih, 2005) on three subjects who were willing to be polygamous found that subjects understood this to be contrary to feelings and ego as a woman. However, as their wives they carry it out with all the consequences that exist, and the problems that occur try to be resolved in the corridors that have been determined by religion.

Basically, according to the results of the research, all informants did not agree with the marriage of polygamy, but there were indeed things that made them lose their ego as a woman. What's more when it came to hereditary affairs or about the interests of many people the woman or someone who is very wise, when her happiness is at stake for the interests of others she loves and the interests of the people, so just try to be patient and after that reach the peak for Patient with the existence of several negative impacts that have to do with psychological problems to the reproductive health of women, of course researchers want to explore how the management or how to overcome the negative impacts that occur in polygamous marriage. With the existence of several negative impacts in the form of health problems experienced by women who are polygamous, on average they choose to overcome these problems by visiting or consulting and also checking their health status, and there are a small number of those who choose only to surrender themselves and concentrate more on worship, so they will naturally get healing.

When a woman suffers from a disease in their reproductive system, the thing to do is consult a doctor. The sooner the problem is addressed or dealt with, the more likely it is to be able to deal with these diseases. (Allert Noya, 2016)

The government has made several efforts in supporting the improvement of public health status, especially for women who are in fact someone who will give birth to the next generation, who will care for their babies until they will be born and continue to grow, so that women must receive special attention in their life reproductive health, where it is a woman's assets that can not be bought by anything.

From the results of this study, it is hoped that the public will understand more about women's reproductive health, both symptoms, treatment problems, overcome existing problems, and knowledge about reproductive health. It is expected that women also care about reproductive health in the form of being able to prevent or prevent health problems. female reproduction.

The status of polygamy marriages in this study was official on two informants, and the status was informal or carried out under the hands, or usually called siri in eight others. The marriage recognized by PA (religious court) among the ten informants, was informant 58 , wherein there is in the informant 5, giving the status of an official wife to the honey, because he is able to give offspring to her husband and at the same time to her, because it was her first wife who brought children directly from the results of the marriage. And different from the reason for the 8th informant who gave her husband's permission for fear of being left behind and divorced by her husband.

Indonesia as a state law addresses the issue of polygamy with very detailed discussion. Clearly there are more or less 5 guidelines as a rule about polygamy, namely Law No. 1 of 1974, PP No. 9 of 1975, PP No. 10 of 1983, PP No. 45 of 1990, and Compilation of Islamic Law (KHI). Based on Law No. 1 of 1974 which states that the family system adopted by the State of Indonesia is even though in principle a person must be monogamous / monogyny but in the following explanation allows a person to polygamy, provided that the court can give permission to the husband to polygamy with the consent of the parties concerned.

In relation to this, the husband, if he wants to take polygamy, must submit a request to the local court. In this case the court first considers the condition of the wife in terms of morality and health 
conditions, especially reproduction. After all these things have been fulfilled, there must be approval from the parties concerned, perhaps the important oral or written agreement is submitted before the court and guarantees financial welfare as evidenced by income, income tax, and other information needed by the husband's court.

In addition there are basic requirements that must be fulfilled by a husband, namely the ability of polygamy to a maximum of 4 people and the husband is able to be fair. If these conditions are not met, the husband is forbidden to do polygamy. Civil). Government regulations in this case the requirements contained in Law No. 1 of 1974, PP No. 9 of 1975, and Compilation of Islamic Law (KHI), there are special provisions stipulated in PP No. 10 of 1983 and PP No. 45 of 1990. For Civil Servants who wish to have more than one wife, they must obtain permission from the official. For female civil servants, they are not permitted to become the second / third / fourth wife. In addition to submitting to court, the husband must first submit in writing to officials accompanied by complete reasons.

If in reality civil servants carry out polygamy without an agreement from an official who will get 4 possible penalties, it could be a lower level of demotion, exemption from office, a respite at his own request, and disrespectful dismissal as a civil servant. Based on Law No.1 of 1974 clearly states that although in writing provides a bright spot for the perpetrators of polygamy, but in fact this law emphasizes to prefer to have dialogue. This is clearly seen how the conditions must be fulfilled. Although consideration of the condition of a wife is considered very vulnerable to unhappiness, it is more due to helplessness which becomes the subject of destiny. However, the law prioritizes a wife's feelings rather than polygamy.

If there is permission from the wife / wife, it is a reflection of the authority of the wife / wives. How very kind of a wife who when her husband applied for her permission to polygamy she was in a condition that desperately needed attention and support. One thing that is actually difficult to be accepted by the instincts of feeling at 7 See PP No. 10 of 1983 article 4 PP No. 30 of 1980 article 6 paragraph 4 the wife is wracked with a burden that is very shocking to the soul, the husband wants to share his love with others.

Polygamy marriages are like Unregistered Marriages which are capable of having the same status in government or legally religious, in this study the status of polygamy is official and there is also a status that is limited to siri marriage or under the hands, and on average they have polygamous status only religiously or underhanded, but a small number of them have official polygamous marital status.

The pattern of life for women's reproductive health In this theme, which uses contraception, a number of 8 informants, and two informants did not use contraception, namely informants 5 and 10 , because they experienced infertility. Regarding the sexual pattern of all respondents, all of them experienced changes, beginning to undergo polygamy. Reproductive health is an effort to maintain health regarding the means of reproduction along with sexual behaviour that is found in someone (Nugrraha, 2015).

In the marriage of polygamy it is also very important to know the pattern of reproductive health life of polygamous women, because polygamy itself is said to have many bad factors, one of which is health factors, and psychological factors, women in polygamous marriages are said to be detrimental to women, even though there are polygamous marriages that some people or groups actually want. In this study they use contraception on average and a little do not use contraception, and for their sexual lives they all say things change and are very different from when they not in polygamy.

\section{CONCLUSION}

The reason for the unregistered marriage can be concluded, that among other things due to heredity, responsibility, business or for the good name of the institution, economy, marriage background with his previous wife, or by reason of the absence of cheating between husband and wife and the husband who feels his wife already unable to provide service or service it perfectly.

The period of unregistered marriage carried out by informants is from 2 until 10 years. However, this does not guarantee that those who have a longer period of time can have more harmonious relationships than those who have a shorter period of time.

The positive impact of unregistered marriage in this study was to get generation. And the negative impact is a psychological problem, namely stress and reproductive problems in the form of menstrual cycle disorders, disminore, vaginal discharge and abortion, also infertile. 
In the case of the agreement given by the wife to the husband to commit polygamy in this study, the average polygamous marriage occurred not with the agreement of a previous wife, but there were several previous wives who gave their husband permission to remarry with consideration that they must have thought about.

The management or how to deal with negative impacts that occur in women who experience psychological disorders that have an impact on reproductive health in women in Pamekasan. Usually, they choose to overcome these problems by visiting or consulting, and also checking their health status, and there are a small number of those who choose only to surrender themselves and concentrate more on worship, so that they believe they will get natural healing.

The status of unregistered marriage in this study on average has a status of polygamy that is legally religious or underhanded, but a minority of them have official polygamous marital status.

On average, the reproductive health patterns of women in this study use contraceptives and some do not use contraception, and for their sexual lives they all say things change and are very different when they were not in polygamy

\section{REFERENCES}

Notoatmodjo, S. (2008). Metodologi Penelitian Kesehatan. Jakarta:Rineka Cipta

Manuaba, 2009. Ilmu Kebidanan Penyakit Kandungan dan KB . Jakarta : EGC.

Prawiroharjho, 2009.Ilmu Kebidanan. Jakarta : Bina Pustaka Sarwono Prawiroharjho.

Depkes. 2003. Kesehatan Reproduksi. Jakarta: Depkes RI

Ariyani, Mira. 2004. Faktor yang Berperan dan Proses yang Terjadi Dalam Keputusan Perempuan Dewasa Untuk Menjadi Istri Kedua Pada Pernikahan Poiligami. Skripsi Sarjana. Depok : Fakultas Psikologi Universitas Indonesia.

BKKBN,2003.Kamus Istilah Kependudukan Keleuarga Berencana dan Keluarga Sejahtera, Jakarta.

Notoatmojho, Soekidjo. Promosi Kesehatan dan Perilaku Kesehatan, Jakarta.Rineka Cipta. 2008

Sugiyono, (2013). Metode Penelitian Kuatitatif, Kualitatif dan R\&D. Bandung: Alfabeta.CV

Moleong, 2007. Metodologi Penelitian Kualitatif. Bandung : Remaja Karya.

Jamhuri, 2006. Transformasi Perempuan Jawa. Surakarta : Pustaka Cakra.

2007. Profil Kesehatan Indonesia. http://www.depkes.go.id. Diakses tanggal 20 januari 2017.

, 2009. Pencegahan Kanker Leher Rahim. http://www.depkes.go.id Diakses tanggal 20

Desember 2016.

2010. Rencana Pembangunan Kesehatan Menuju Indonesia Sehat. Availabel at. http://www.depkes.go.id. Diakses tanggal 10 januari juni 2017

Dianawati A. 2003. Pendidikan seks untuk remaja. Jakarta : Kawan Pustaka

Daili.Sf., 2007. Tinjauan Penyakit menular seksual(PMS).In: Djuanda,A,. Hamzal, M.,\&Aisah.Ilmu Penyakit Kulit Dan Kelamin. $5^{\text {th }}$ ed. Jakarta : Balai Penerbit FKUI . , 2009.Gonorea, Infeksi Menular Seksual $4^{\text {th }}$ ed. Jakarta : Balai Penerbit FKUI . 
Dickson, Anne L. 2007. Pandangan Ibu-Ibu 'Aisyiyah di Malang terhadap Poligami. Skripsi

Sriningsih, Wiwik. 2009. Poligami menurut Masyarakat Awam, Priyayi, dan Ulama Ditinjau dari Segi Hukum Islamdan Hukum Positif Indonesia. Skripsi (tidak diterbitkan). Twinninng Programe Fakultas Hukum dan Fakultas Agama Islam UMS.

Soewondo, S. 2001. Keberadaan pihak ketiga, poligami dan permasalahan perkawinan (Keluarga) ditinjau dari aspek psikologi. Dalam (Munandar,S. C. U. (Ed.), Bunga Rampai Psikologi Perkembangan Keperibadian dari Bayi Sampai Lanjut Usia. (154-183). Jakarta: UI Press.

Andi, 2014, Dampak yang Umum terjadi Terhadap Istri yang Suaminya Berpoligami Departemen Kesehatan Republik Indonesia, Dirjen Pembinaan Kesehatan

Perkawinan.Yogyakarta:.http://bsi-actions.indonesianforum.net/t62-dampak-poligamiterhadap-wanita-indonesia. Diakses Tanggal 26 Januari 2011 